\title{
Ipsilateral Fallopian Tube and Ovary Agenesis or Absence? Case Report and Review of the Literature
}

\author{
Galli $\mathrm{PA}^{1}$ and Princi $\mathrm{D}^{2 *}$ \\ ${ }^{1}$ Obstetric Gynecologist Consultant, Italy \\ ${ }^{2}$ Medical Manager, UOC Obstetrics \& Gynecology, Italy
}

Submission: November 12, 2017 ; Published: December 18, 2017

*Corresponding author: Princi D, Medical Manager, UOC Obstetrics \& Gynecology Adria- ULSS n.5 Polesana (R0), Italy, Tel: +39 337589091;

Email: dott.paologalli@gmail.com

\begin{abstract}
The ipsilateral absence of fallopian tube and ovary is rare. The etiology is not clear and the esteemed incidence is 1:11.240. The unilateral absence is rarely associated to genital and extra-genital malformations. We refer the case of 21 years of women who declared primary amenorrhea and dyspareunia. She was found affected by mammary Tanner stage 3; low 17-ßestradiol and high FSH and LH levels; BMI 32.2; delayed bones development; moderate hyperinsulinemia; normal karyotype. No urinary apparatus anomalies. Her homozygote twin-sister is normal. The diagnostic laparoscopy shows uterine hypoplasia, normal right fallopian tube and ovary and complete absence of left tube and ovary. A review of literature is reported. The patient is now under sequential estro-progestinic treatment and on a diet to improve hypogonadism, sexual life and metabolic system.
\end{abstract}

Keyword: Adnexa agenesis

\section{Introduction}

The unilateral agenesis and/or absence of ipsilateral fallopian tube and ovary (adnexa) is rare and rarely described in the literature. The esteemed incidence is 1:11.240 [1,3]. The etiology is not clear: ipsilateral tubal and ovarian absence could be caused by the torsion of ovarian peduncle before birth or before puberty [2,3]. Adnexa agenesis is always associated to uterine and to urinary apparatus malformations; unilateral agenesis or absence are rarely associated to genital and extragenital malformations. The majority of affected patients has no special symptoms and signs and the diagnosis follows a laparoscopy or a laparotomy performed for different causes. We report the case of young women affected by primary amenorrhea and review the literature regarding adnexal agenesis and/or absence.

\section{Case Report}

S.V. 21 y. o., 93Kg, $170 \mathrm{~cm}$ high (BMI: 32.2) comes to our Maternity Unit because of primary amenorrhea and dyspareunia. Her homozygote twin sister is regularly menstruated since age 13 and has no gynecological problems.

Modest hyperinsulinemia $(13.4 \mathrm{UI} / \mathrm{ml})$, low $17-\beta$-estradiol $(<10 \mathrm{pg} / \mathrm{ml})$ and high FSH $(54.2 \mathrm{mU} / \mathrm{ml})$ and $\mathrm{LH}(15 \mathrm{mU} / \mathrm{ml})$ levels depose for an hyper-gonadotropic hypogonadism. At inspection extern genitals appear normal; moderate presence of pubic hair; mammary development at Tanner stage 3 [4]. Striae rubrae are present on both flanks and subcutaneous fat and body hair distribution are of normal feminine habitus. At exploration and inspection the vagina seems normal; cervical hypoplasia with a punctiform external orifice. At transvaginal echography uterus appears hypo-plastic with no endometrial thickness. The right ovary has reduced volume: a little follicle is visible. Left ovary not detectable. RX for bone age (Figure 1) shows transparent rhymes at proximal phalanges and at distal ulnar and radial extremities which prove a delay in bone development for age.

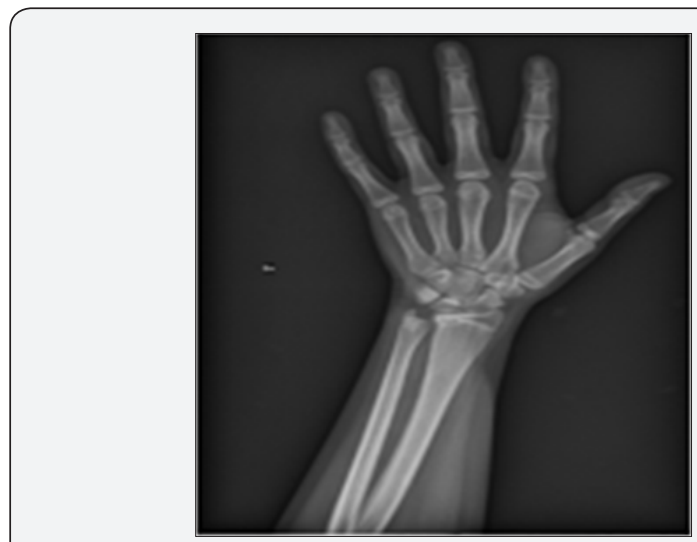

Figure 1: Left hand: delayed bones development.

Karyotype is 46, XX with absence of sequences at locus SRY. Diagnostic laparoscopy shows an hypo-plastic uterus with normal round ligaments; normal right fallopian tube and right ovary seat of little cyst which is aspirated; total absence of left 
tube and ovary; no pelvic adhesions (Figure 2). A successive NMR excludes urinary tract anomalies [5]. After multidisciplinary counselling the patient has been treated with trans-dermic lowering natural estrogens with the attempt to stimulate the secondary sexual characters and to reduce FSH and LH levels and induce menarca. Afterward, natural progesterone per as has been added to sham ovarian cycle.

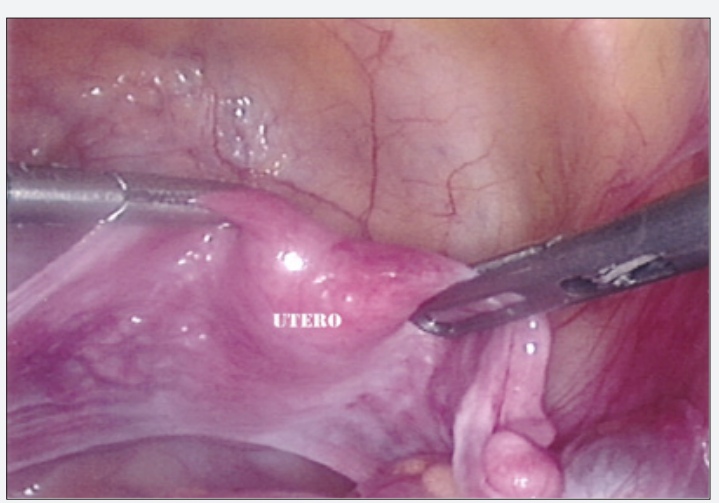

Figure 2: Laparoscopy Hypoplasia of uterus and right fallopian tube and ovary. Absence of left adnexa.

\section{Discussion}

Unilateral agenesis of adnexa is rarely reported in literature: it seems to be even more rare in absence of uterine anomalies. A review of literature (PubMed) reports 28 cases (Table 1): five cases are associated to urinary tract malformations [6-9]; five cases are associated to uterine anomalies [6,9-12]; three cases signal contemporary endometriosis $[3,7,9]$; twelve cases are associated to primary sterility $[1-3,12-16]$. In three cases of tube and ovary agenesis is present a contra lateral stenotic tube $[1,3,15]$ and in two cases is present a contralateral ovarian cyst $[17,18]$. Our patient never had spontaneous menarca: one only similar case is reported in literature [12] typefied by hypoplastic uterus, normal karyotype, primary amenorrhea and sterility but this case had bilateral ovarian agenesis and absence of distal tract of both fallopian tubes.

With regard to etio-pathogenesis, is known that the malformation of our clinic case includes organs originating from Muller ducts and from yolk sac mesoderma. During the sixth week of gestation Muller ducts migrate on the median line and their fusion creates the uterus and the proximal tract of the vagina. Rostrally the Muller ducts create the fallopian tubes. The gonads instead derivate from migration of mesodermal primordial germinal cells of the yolk sac to the genital crests giving origin to the sexual cordons. In case of male embryo the SRY gene of the short Y arm [19] keeps the sexual cordons proliferating deep in the medullar and creates the seminiferous tubules. When the embryo is female, the sexual cordons split in series of cellular heaps of granulosa cells surrounding the primordial germinative cells.

Table 1: Unilateral Fallopian tube and ovarian agenesis: literature review.

\begin{tabular}{|c|c|c|c|c|c|}
\hline Author & $\begin{array}{l}\text { Uterine Associated } \\
\text { Malformation }\end{array}$ & Infertility/ Sterility & $\begin{array}{l}\text { Urinary Apparatus } \\
\text { Associated } \\
\text { Malformations }\end{array}$ & $\begin{array}{c}\text { Associated } \\
\text { Endometriosis }\end{array}$ & Notes \\
\hline Pabuccu [13] & Unknown & Yes & No & No & \\
\hline Vaiarelli [24] & No & Yes & Unknown & No & $\begin{array}{l}\text { Right ovary absence; } \\
\text { right fallopian tube } \\
\text { anomaly }\end{array}$ \\
\hline Eustace [2] & No & Yes & No & No & \\
\hline Sivanesaratnam [15] & No & Yes & No & No & $\begin{array}{c}\text { Contralateral tubal } \\
\text { stenosis }\end{array}$ \\
\hline Uckuyu [16] & No & Yes & No & No & $\begin{array}{l}\text { Left tubal distal tract } \\
\text { absence and left } \\
\text { ovarian agenesis. }\end{array}$ \\
\hline Uckuyu [16] & No & Yes & No & No & \\
\hline Uckuyu [16] & No & Yes & No & No & $\begin{array}{l}\text { Casual check up } \\
\text { during surgical } \\
\text { detorsion of contra } \\
\text { lateral fallopian tube } \\
\text { torsion. }\end{array}$ \\
\hline Rapisarda [2] & No & Yes & No & No & $\begin{array}{c}\text { Contra lateral tubal } \\
\text { stenosis }\end{array}$ \\
\hline Suh [10] & Septed Uterus & Yes & No & No & \\
\hline Eustace [2] & No & No & No & Unknown & $\begin{array}{l}\text { Diagnosis during } \\
\text { tubal sterilization }\end{array}$ \\
\hline Sivanesaratnam [15] & No & No & No & No & \\
\hline Haydardedeoglu [6] & Unicorne Uterus & Unknown & $\begin{array}{l}\text { Ipsilateral kidney } \\
\text { Agenesis }\end{array}$ & No & \\
\hline
\end{tabular}


Journal of Gynecology and Women's Health

\begin{tabular}{|c|c|c|c|c|c|}
\hline Mulayim [9] & Bicornuate Uterus & Unknown & $\begin{array}{l}\text { Ipsilateral pelvic } \\
\text { kidney }\end{array}$ & $\begin{array}{c}\text { Modest } \\
\text { Endometriosis }\end{array}$ & \\
\hline Demir [11] & Unicorne uterus & No & No & No & $\begin{array}{c}\text { Casual check u during } \\
\text { Cesarean section. }\end{array}$ \\
\hline Gold [12] & Hypoplastic Uterus & $\begin{array}{c}\text { Primary } \\
\text { Amenorrhoea }\end{array}$ & No & No & $\begin{array}{l}\text { Bilateral absence of } \\
\text { ovaries and of the } \\
\text { distal tract of tubes }\end{array}$ \\
\hline Muppala [7] & No & No & $\begin{array}{c}\text { Ipsilateral kidney } \\
\text { Agenesis }\end{array}$ & $\begin{array}{c}\text { Moderate } \\
\text { Endometriosis }\end{array}$ & $\begin{array}{l}\text { Associated piloric } \\
\text { stenosis and absence } \\
\text { of ipsilateral round } \\
\text { ligament }\end{array}$ \\
\hline Zaitoon [8] & No & No & $\begin{array}{c}\text { Bilateral kidneys } \\
\text { Ectopy }\end{array}$ & No & \\
\hline Mylonas [3] & No & No & No & $\begin{array}{c}\text { Moderate } \\
\text { Endometriosis }\end{array}$ & \\
\hline Mylonas [3] & No & No & No & No & \\
\hline Mylonas [3] & No & $\mathrm{Si}$ & No & No & $\begin{array}{l}\text { Contralateral tubal } \\
\text { stenosis }\end{array}$ \\
\hline Gotti [21] & No & No & No & No & $\begin{array}{l}\text { Observed during } \\
\text { surgical operation } \\
\text { for extra uterine } \\
\text { pregnancy }\end{array}$ \\
\hline Petersen [22] & No & No & No & No & $\begin{array}{l}\text { Associated to anal } \\
\text { atresia }\end{array}$ \\
\hline Dueck [23] & No & No & No & No & $\begin{array}{c}\text { Presence of } \\
\text { contralateral ovarian } \\
\text { cysts }\end{array}$ \\
\hline Gursoy [24] & No & No & $\begin{array}{c}\text { Ipsilateral kidney } \\
\text { Agenesis }\end{array}$ & No & \\
\hline Мa [25] & No & No & No & No & Omentum Teratoma \\
\hline Georgy [26] & No & No & No & No & $\begin{array}{l}\text { Observed during } \\
\text { hysterectomy }\end{array}$ \\
\hline Sirisena [27] & No & No & No & No & $\begin{array}{c}\text { Presence of } \\
\text { contralateral ovarian } \\
\text { cysts }\end{array}$ \\
\hline
\end{tabular}

The agenesis of both ipsilateral ovary and fallopian tube with normal uterus is an embryologic condition difficult to explain. Some studies speculate a defect of the genital crest and of the caudal area of the Muller ducts caused by an insufficient vascularization during migration in the pelvis of the caudal section of the para-mesonefrum $[2,3,18]$. Other studies support 1) an asymptomatic adnexal torsion with secondary ischemia and reabsorption $[2,3,18], 2)$ a congenital absence due to a defect in development of the Muller ducts and of the ipsilateral genital crest $[2,7,15,18], 3)$ a vascular anomaly cause of ischemia in prenatal life [11]. Literature reports the case of a women who ten years before diagnosis of right fallopian tube and ovary absence had an important and persistent pain in the right ovarian region. The authors $[19,20]$ speculate an ovarian torsion with further ischemia and adnexal re-absorption [20-27].

\section{Conclusion}

In our clinic case, the normal karyotype with absence of SRY gene exclude a condition correlated to a genetic cause. Also the peculiar homo-zygotic twins trails to a noxa happened after the embryologic development of the sexual organs. Moreover, the contra lateral hypogonadism and the uterine hypoplasia suggest the presence of contemporary factors however happened after the embryologic period. For these reasons we suppose a distinction between agenesis and absence. The treatment with estrogens and estro-progestins as well as an adequate diet has the intent to induce the uterine and the secondary sexual characters development as well as to improve the sexual life and the metabolic system.

\section{References}

1. Rapisarda G, Pappalardo EM, Arancio A, La Greca M (2009) Unilateral ovarian and fallopian tube agenesis. Arch Gynecol Obstet 280(5): 849850.

2. Eustace DL (1992) Congenital absence of fallopian tube and ovary. Eur J Obstet Gynecol Reprod Biol 46: 157-159.

3. Mylonas I, Hansch S, Markmann S, Bolz M, Friese K (2003) Unilateral ovarian agenesis: report of three cases and review of literature. Arch Gynecol Obstet 268(1): 57-60.

4. Asma J, Aida L (2013) Development of the Human Breast. Semin Plast Surg 27(1): 5-12. 
5. Elkington N, Rahman R (2008) Unexplained unilateral absence of fallopian tube and ovary. The Internet Journal of Gynecology and Obstetrics 11

6. Haydardedeoglu B, Simsek E, Kilicdag EB, Tarim E, Aslan E, et al. (2006) A case of unicornuate uterus with ipsilateral ovarian and renal agenesis. Fertil Steril 85(3):750.

7. Muppala H, Sengupta S, Martin JE (2008) Unilateral absence of tube and ovary with renal agenesis and associated pyloric stenosis: communication. Eur J Obstet Gynecol Reprod Biol 137(1): 123.

8. Zaitoon MM, Florentin H (1982) Crossed renal ectopia with unilateral agenesis of fallopian tube ad ovary. J Urol 128(1): 111.

9. Mulayim B, Demirbasoglu S, Oral O (2003) Unicornuate uterus and unilateral ovarian agenesis associated with pelvic kidney. Surg Endosc 17(1): 161 .

10. Suh BY, Kalan MJ. (2008) Septate uterus with left fallopian tube hypoplasia and ipsilateral ovarian agenesis. J Assist Reprod Genet 25(11-12): 567-569.

11. Demir B, Guven S, Guvendag GES, Gunalp GS (2007) An incidental finding of unicornuate uterus with unilateral ovarian agenesis during cesarean delivery. Arch Gynecol Obstet 276(1): 91-93.

12. Gold MA, Schmidt RR, Parks N, Traum RE (1997) Bilateral absence of the ovaries and distal fallopian tubes: a case report. J Reprod Med 42(6): 375-377.

13. Pabuccu E, Kahraman K, Taskın S, Atabekoglu C (2011) Unilateral absence of fallopian tube and ovary in an infertile patient. Fertil Steril 96: e55-e57.

14. Vaiarelli A, Luk J, Patrizio P (2012) Ectopic pregnancy after IVF in a patient with unilateral agenesis of the fallopian tube and ovary and with endometriosis: search of the literature for these associations. J Assist Reprod Genet 29: 901-904.

15. Sivanesaratnam V (1986) Unexplained unilateral absence of ovary and fallopian tube. Eur J Obstet Gynecol Reprod boil 22: 103-105.
16. Uckuyu A, Ozcimen EE, Sevinc Ciftci FC (2009) Unilateral congenital ovarian and partial tubal absence: report of four cases with review of literature. Fertil Steril 91: 936 e5-e8.

17. Saitou M, Barton SC, Surani MA (2002) A molecular programme for the specification of germ cell fate in mice. Nature 418(6895): 293-300.

18. Paternoster DM, Costantini W, Uglietti A, Vasile C, Bocconi L (1998) Congenital or torsion-induced absence of fallopian tubes. Two case reports. Minerva Ginecol 50(5): 191-194.

19. Bingya C, Chunbo Y, Zayd S, Hangmei J (2014) Unilateral ovarian and fallopian tube agenesis in an infertile patient with a normal uterus. Exp Ther 8(3): 831-835.

20. Dahan MH, Burney R, Lathi R (2006) Congenital interruption of the ampullary portion of the fallopian tube. Fertil Steril 85(6): 1820-1821.

21. Gotti G, Ferrone R, Andreoli M, Turini A, Russo P, et al. (2008) Agenesia o assenza annessiale monolaterale? Descrizione di un caso clinico. It J Gynaecol Obstet 20(2): 87-89.

22. Petersen KR, Brooks L (1982) Anal atresia combined with unilateral agenesis of the ovary and uterine tube. Ugeskr Laeger 144(21): 15511552.

23. Dueck A, Poenaru D, Jamieson MA, Kamal IK (2001) Unilateral ovarian agenesis and fallopian tube maldescent. Pediatr Surg Int 17(2-3): 228229.

24. Gursoy AY, Akdemir N, Hamurcu U, Gozukucuk M (2013) Incidental diagnosis of unilateral renal and adnexal agenesis in a 46-year-old multiparous woman. Am J Case Rep 14: 238-240.

25. Ma CL (2006) Greater omental teratoma with congenital absence of the left ovarian: report of 2 cases. Chin J Clin Obstet Gynecol 7: 302.

26. Georgy FM, Viechnicki MB (1974) Absence of an ovary and uterine tube. Obstet Gynecol 44(3): 441-442.

27. Sirisena LA (1978) Unexplained absence of an ovary and uterine tube. Postgrad Medical J 54(632): 423-424.

\section{Your next submission with Juniper Publishers will reach you the below assets}

- Quality Editorial service

- Swift Peer Review

- Reprints availability

- E-prints Service

- Manuscript Podcast for convenient understanding

- Global attainment for your research

- Manuscript accessibility in different formats

( Pdf, E-pub, Full Text, Audio)

- Unceasing customer service

Track the below URL for one-step submission https://juniperpublishers.com/online-submission.php 